\title{
Manajemen Komunikasi Marketing LAZISNU Kota Bandung
}

\author{
M. Abdul Ghani \\ Pengurus Cabang Nahdatul Ulama Kota Bandung \\ agighani99@gmail.com
}

\begin{abstract}
This study aims to analyze communication management of LAZISNU Bandung to encourage people in handing over charity, management activities undertaken by LAZISNU city, and management LAZISNU in distributing money to the charity (mustahiq). The method used in this study is a phenomenological method, using a qualitative approach. In collecting data techniques this study uses interview, observation, literature review and assessment documentation. The results of this study indicate that the use of communications LAZISNU Bandung to attract people's trust, using two models of communication and marketing, which is the above line and the below line. Event management is performed by lazisnu Bandung already run well, including planning, organizing, monitoring, and NU Skill, NU Preneur, NU Smart, dan NU Care.
\end{abstract}

Keywords: Management, Communication, Marketing

\begin{abstract}
ABSTRAK
Penelitian ini bertujuan untuk menganalisis manajemen komunikasi Lazisnu kota Bandung kepada masyarakat dalam mendorong mereka menyerahkan zakat, kegiatan manajemen yang dilakukan oleh Lazisnu kota Bandung, dan manajemen Lazisnu membagikan uang zakat kepada para mustahiq. Metode yang digunakan pada penelitian ini adalah metode fenomenologi, dengan menggunakan pendekatan kualitatif. Sedangkan untuk teknik pengumpulan datanya, penelitian ini menggunakan teknik wawancara mendalam, Observasi lapangan, pengkajian kepustakaan, serta pengkajian dokumentasi. Hasil penelitian ini menunjukkan bahwa komunikasi yang digunakan Lazisnu Kota Bandung untuk menarik kepercayaan masyarakat, menggunakan dua model komunikasi marketing sekaligus, yakni above the line dan below the line. Kegiatan manajemen yang dilakukan oleh lazisnu Kota Bandung sudah berjalan, meliputi perencanaan, pengorganisasian, pengawasan, dan evaluasi. Lazisnu Kota Bandung menyalurkan dana zakat, infaq, dan shadaqah, melalui 4 program unggulan, yakni NU Skill, NU Preneur, NU Smart, dan NU Care.
\end{abstract}

Kata Kunci : Manajemen, Komunikasi, Marketing 


\section{Pendahuluan}

Zakat merupakan suatu kegiatan penting yang diperintahkan oleh Tuhan kepada umat manusia. Bahkan tak hanya umat Islam yang mewajibkan dirinya untuk membayar zakat, namun agama lain sperti Kristen pun diwajibkan oleh ajarannya untuk membayar zakat.

Pada dasarnya, kegiatan pembayaran zakat memang bisa dilakukan di sembarang tempat, tanpa harus melibatkan 'amil (orang yang bertugas mengelola dan membagikan zakat) di dalamnya. Seorang muгakki (pembayar zakat), dapat saja membagikan langsung uang zakatnya kepada para mustabiq (penerima zakat), tanpa perlu melibatkan 'amil, atau bahkan menunjuk siapa saja yang dianggap kredibel dan dapat dipercaya untuk menjadi amil.

Akan tetapi, jika zakat dikelola secara personal, maka hal ini dikhawatirkan rentan sekali terjadi kecurangan. Selain rentan terjadi kecurangan, zakat yang dikelola secara personal juga diyakini tidak akan terjadi pemerataan pembagian zakat kepada para mustahiq-nya. Hampir bisa dipastikan jika pengelolaan zakat dilakukan secara personal, maka para mustahiq yang menerima aliran dana zakat hanya orang yang itu-itu saja, atau hanya orang yang berada di sekitar sang muqakki. Sedangkan para mustahiq yang diluar jangkauan, hanya akan gigit jari.

Dengan hadirnya sebuah Lembaga Zakat, para muzakki kini akan lebih diringankan. Mereka tak lagi harus membagikan zakatnya sendiri, atau mereka juga tak lagi mesti mencari orang yang dapat dipercaya untuk mengelola zakat. Dengan adanya Lembaga Zakat, diharapkan bisa menjadi solusi bagi pemerataan pembagian zakat kepada para mustahiq.

Selain itu, zakat yang dikelola oleh sebuah lembaga amil memiliki beberapa keuntungan, antara lain, lebih mengena dengan ajaran syari'ah karena amil termasuk kedalam 8 golongan yang berhak mendapatkan zakat, adanya jaminan yang diberikan lembaga amil kepada muzakki, mencegah adanya perasaan malu dari seorang mustahik jika langsung bersinggungan dengan muzakki, zakat yang dikelolanya lebih efektif dan efisien, serta menjadi syi'ar Islam yang khas (Beik, 2009: 3. Vol: 2. No. 1).

Namun demikian, dengan hadirnya Lembaga Zakat pun tidak serta merta membuat masyarakat -khususnya para muzakki- percaya akan kredidilitas yang dimiliki lembaga tersebut. Ketidak percayaan ini setidaknya dipicu oleh dua hal, pertama, karena para muzakki khawatir zakat mereka tidak sampai ke tangan mustahiq, kedua, para muzakki tidak 
percaya kepada lembaga zakat yang memiliki paham keislaman berbeda dengan mereka.

Hadirnya Lembaga Amil Zakat Infaq dan Shadaqah Nahdlatul Ulama (Lazisnu) menjadi angin segar bagi masyarakat yang ketidakpercayaannya berangkat dari poin kedua diatas, khususnya bagi warga Nahdlatul Ulama sendiri. Lazisnu merupakan lembaga pembantu dari ormas Islam terbesar se-Asia Tenggara, Nahdlatul Ulama (NU).

Organisasi Nahdlatul Ulama (NU) memiliki pengurus di hampir seluruh wilayah Indonesia. Untuk mengkoordinir anggota dan jamaahnya yang tersebar luas di sudut-sudut bumi pertiwi, NU pun memiliki tingkatan kepengurusan dari mulai Pengurus Besar (PB) yang menjadi pusat kepengurusan NU, Pengurus Wilayah (PW) yang melingkupi skala provinsi, Pengurus Cabang (PC) yang melingkupi skala Kabupaten/Kota, Pengurus Cabang Istimewa (PCI) yang melingkupi NU di luar negri, Majlis Wakil Cabang (MWC) yang melingkupi skala kecamatan, dan Ranting yang melingkupi skala Kelurahan/Desa. Sama halnya dengan kepengurusan NU, Lazisnu pun memiliki tingkatan kepengurusan sesuai dengan tingkatan kepengurusan NU yang ada. Ada PB Lazisnu, PW Lazisnu, PC Lazisnu, PCI Lazisnu, MWC Lazisnu, hingga Ranting Lazisnu. Namun untuk kepengurusan Lazisnu dibawah skala Kabupaten/Kota, hanya berbentuk UPZ (Unit Pengumpul Zakat) saja, tanpa adanya kepengurusan yang resmi sebagaimana Lazisnu di tingkat Kabupaten/Kota ke atas.

Lazisnu pertama yang diresmikan secara administratif oleh Kementrian Agama Republik Indonesia adalah Lazisnu Jombang, dengan Surat Keputusan (SK) Nomor: 65 Tahun 2005 tentang Pengukuhan Lembaga Amil Zakat Infaq dan Shodaqoh Nahdlatul Ulama (Lazisnu) sebagai Lembaga Amil Zakat Nasional (LAZNAS). Sedangkan Lazisnu Kota Bandung resmi mendapatkan SK dari pusat pada Tahun 2013, dengan kata lain, belum genap tiga tahun Lazisnu Kota Bandung beroprasi.

Lazisnu diresmikan menjadi sebuah Lembaga pembantu Pengelolaan zakat, infaq, dan Shadaqah di tubuh Pengurus Besar Nahdlatul Ulama (PBNU), terhitung sejak Muktamar NU ke-31 pada tahun 2004 di Surakarta, dengan Prof. DR. KH. Fathurrahman Rauf sebagai Pimpinan pertama Lazisnu Pusat. Selanjutnya pada Muktamar NU ke-32 tahun 2010 di Makassar, kepemimpinan Lazisnu Pusat yang dipegang oleh Prof. DR. KH. Fathurrahman Rauf, digantikan oleh Drs. KH. Masyhuri Malik. Sedangkan di kota Bandung sendiri, saat ini Pengurus Cabang (PC) Lazisnu di pimpin oleh KH. Umar Mansur. 
Selayaknya sebuah organisasi, Lazisnu juga memiliki sebuah visi yang mana dengan visi tersebut, mereka berharap Lazisnu bisa menjadi salah satu organisasi yang berguna bagi masyarakat. Adapun visi dari Lazisnu, adalah "Bertekad menjadi lembaga pengelola dana masyarakat (zakat, infaq, shodaqoh, CSR, dan lain-lain) yang didayagunakan secara amanah dan profesional untuk kemandirian umat" (mmm.lazisnujabar.or.id).

Untuk menunjang visi Lazisnu diatas, maka perlu ada sebuah misi yang dilakukan agar visi tersebut dapat diwujudkan. Berikut adalah misi dari Lazisnu, yang dikutip dari situs resmi Lazisnu: 1) Mendorong tumbuhnya kesadaran masyarakat untuk mengeluarkan zakat, infaq, dan shodaqoh dengan rutin dan tepat sasaran. 2) Mengumpulkan/menghimpun dan mendayagunakan dana zakat, infaq, dan shodaqoh secara professional transparan tepat guna dan tepat sasaran. 3) Menyelenggarakan program pemberdayaan masyarakat guna mengatasi problem kemiskinan, pengangguran dan minimnya akses pendidikan yang layak (wmm.lazisnujabar.or.id).

Namun demikian, nama Lazisnu dapat dibilang masih baru di telinga masyarakat. Tidak seperti Badan Amil Zakat (BAZ) yang sudah populer di masyarakat. Hal ini menjadi salah satu indikator, mengapa Lazisnu masih kurang diminati oleh masyarakat. Oleh karena Lazisnu masih terbilang baru, maka upaya-upaya yang dilakukan pun akan lebih gencar, ketimbang lembaga-lembaga lain yang sudah mapan. Hal ini dikarenakan Lazisnu masih merasa belum melakukan hal yang maksimal. Ditambah lagi dengan belum banyaknya muzakki tetap yang selalu setia menyalurkan zakatnya kepada Lazisnu.

Hal ini juga diperparah dengan masih adanya para Kiyai-Kiyai NU yang masih menerima dan mengelola zakat secara personal, tanpa menyalurkannya kepada Lazisnu, yang notabene merupakan lembaga pengelola zakat resmi milik Nahdlatul Ulama. Masyarakat jelas akan lebih memilih menyalurkan zakatnya kepada para Kiyai tersebut, yang sudah lama mereka percaya, ketimbang harus membayar zakat kepada Lazisnu yang masih seumur jagung.

Berangkat dari fenomena tersebut, ada hal menarik yang kiranya bisa diteliti. Yakni mengenai bagaimana cara Lazisnu yang baru berusia sangat muda, mendapatkan kepercayaan masyarakat dan minat masyarakat untuk beralih menyalurkan dana zakatnya kepada Lazisnu. Karena zakat yang dikelola oleh sebuah lembaga resmi akan lebih merata pengelolaannya, ketimbang zakat yang dikelola oleh personal.

Berdasarkan latar belakang masalah sebagaimana diuraikan diatas, maka mini riset ini, difokuskan pada tiga pertanyaan masalah, yakni; 1) 
Bagaimana cara komunikasi Lazisnu kota Bandung kepada masyarakat, agar membuat mereka mau mempercayakan zakatnya kepada Lazisnu kota Bandung. 2) Bagaimana kegiatan manajemen yang dilakukan oleh Lazisnu kota Bandung. 3) Bagaimana cara Lazisnu membagikan uang zakat kepada para mustahiq. Untuk itu, penelitian ini difokuskan pada manajemen komunikasi marketing Lazisnu, dengan memberi judul penelitian sebagai; Manajemen Komunikasi Marketing Lazisnu Kota Bandung dalam Menarik Minat Masyarakat.

\section{Manajemen Komunikasi Marketing}

Manajemen merupakan suatu kegiatan yang bertujuan untuk mencapai sebuah tujuan yang telah ditentukan. Menurut George R. Terry; Manajemen adalah suatu kegiatan yang memiliki ke-khas-an tersendiri, dimana kegiatan tersebut terdiri dari pengorganisasian, perencanaan, pengawasan dan evaluasi yang dilaksanakan guna menetapkan dan mencapai tujuan yang telah ditentukan dengan bantuan sumber daya manusia dan sumber daya lainnya. (Firdaus, 2009: 27). Proses manajerial menurut Terry sekurang-kurangnya terdiri atas 4 proses kegiatan, yakni perencanaan, pengorganisasian, pengawasan, serta evaluasi (Firdaus, 2009: 27).

Perencanaan merupakan buah dari suatu pemikiran yang menggiring kita untuk mencapai suatu tujuan yang telah ditetapkan sebelumnya. Yakni terkait rangkaian tindakan yang didasarkan pada hasil pemikiran mendalam dari berbagai aspek yang terlibat, serta yang ditujukan kepada sasaran. Dengan kata lain, perencanaan merupakan upaya menentukan tindakan yang didasarkan pada pemilihan berbagai alternatif data, yakni yang dirumuskan melalui suatu keputusan yang hendak dikerjakan dalam upaya mencapai tujuan (Firdaus, 2009: 29).

Adapun pengorganisasian merupakan langkah selanjutnya setelah melakukan perencanaan. Tujuan pengorganisasian ialah untuk mengeksekusi rencana yang telah dirancang sebelumnya, untuk mencapai sebuah tujuan yang di inginkan. Pada hakikatnya, terdapat tiga komponen yang mesti ada dalam organisasi, yakni personalia, fungsi, dan faktor sarana fisik. Dalam kegiatan pengorganisasian, sebenarnya tengah mempersiapkan tiga komponen tersebut dengan sangat matang, agar proses pencapaian tujuan dapat berjalan lancar. Oleh karena itu, pengorganisasian juga dapat disebut sebagai suatu proses sinkronisasi antara fungsi, personalia, dan faktor fisik, supaya semua kegiatan yang 
mesti dilakukan disatukan dan diarahkan pada tujuan yang telah ditentukan (Firdaus, 2009: 32).

Setelah proses perencanaan dan pengorganisasian selesai, maka langkah selanjutnya yang mesti dilakukan ialah pengawasan. Pengawasan merupakan kegiatan mendeterminasi apa saja yang telah dilaksanakan (Firdaus, 2009: 35). Pengawasan bertujuan untuk menjadi tolak ukur seberapa baik hasil yang dicapai setelah melakukan proses-proses sebelumnya diatas. Dengan adanya pengawasan, maka kita bisa mengetahui pula, apakah kegiatan yang dilakukan sudah sesuai dengan apa yang direncanakan, dengan pengawasan pula kita bisa tahu, sedekat mana kita dengan tujuan yang diharapkan. Jika usaha yang tengah dilakukan ternyata mengalami kegagalan atau mengalami kendala, maka pengawasan pun berfungsi untuk mengetahui, apa kendala yang menghambat proses kegiatan tersebut.

Jika tiga proses diatas telah dilakukan, maka langkah selanjutnya adalah melakukan evaluasi. Evaluasi bertujuan untuk mengkaji dan meninjau kinerja yang telah dilakukan dalam jangka waktu tertentu. Kegiatan evaluasi ini mesti dilakukan secara berkala, agar jika terjadi kesalahan atau kegagalan, dapat segera dikoreksi serta menemukan solusi agar kegagalan atau kesalahan tersebut tidak terulang kembali (Firdaus, 2009: 39).

Menurut American Marketing Association (AMA) yang dikutip oleh M. Nur Rianto al-Arif, marketing atau pemasaran merupakan "suatu fungsi organisasi dan seperangkat proses untuk menciptakan, mengkomunikasikan, dan menyerahkan nilai kepada pelanggan dan mengelola hubungan pelanggan dengan cara yang menguntungkan organisasi dan para pemilik sahamnya" (Rianto al-Arif, 2012: 6).

Adapun menurut M. Nur Rianto al-Arif sendiri, pemasaran merupakan "suatu proses sosial yang merancang dan menawarkan sesuatu yang menjadi kebutuhan dan keinginan dari pelanggan dalam rangka memberikan kepuasan yang optimal kepada pelanggan" (Rianto al-Arif, 2012: 6).

Sedangkan menurut Philip kotler dan Kevin Lane Keller, "pemasaran adalah suatu proses kemasyarakatan dimana individu dan kelompok memperoleh apa yang mereka butuhkan dan inginkan dengan menciptakan, menawarkan, dan secara bebas mempertukarkan produk dan jasa yang bernilai dengan orang lain" (Kotler dan Keller, 2008: 5).

Melihat beberapa definisi diatas, dapat disimpulkan bahwa kegiatan pemasaran atau marketing adalah salah satu fungsi dari organisasi yang melakukan suatu proses sosial dengan menciptakan, menawarkan, 
mengkomunikasikan suatu barang atau jasa, demi terwujudnya keuntungan bersama baik dari konsumen maupun dari produsen. Inti dari isi marketing ialah gagasan, ide, visi, misi serta program kerja yang sejalan dengan kebutuhan konsumen (Anugrah, 2011: 590. Vol: 2)

Kata marketing atau pemasaran mungkin sudah tidak asing lagi ditelinga masyarakat kita. Bahkan lucunya, masyarakat kerap kali menerka-nerka tentang apa itu marketing atau pemasaran. Tak jarang pula banyak masyarakat awam yang sering mempresepsikan profesi marketer (pemasar) dengan sales (penjual). Padahal kegiatan pemasaran atau marketing jauh lebih luas dari pada anggapan masyarakat kita tersebut.

Kegiatan pemasaran lebih seperti seni dalam menjual suatu produk dengan kesulitan yang berlapis-lapis. Kegiatan pemasaran bukan hanya merupakan kegiatan penjualan seperti yang dilakukan oleh para sales, melainkan kegiatan pemasaran merupakan serangkaian kegiatan yang dilakukan dari mulai perancangan produk, hingga pada saat setelah produk tersebut terjual. Dengan kata lain, kegiatan pemasaran merupakan serangkaian kegiatan yang luas, sedangkan penjualan hanya merupakan bagian dari pemasaran itu sendiri.

Menurut Kotler dan Keller, Terdapat 10 jenis entitas yang dapat dipasarkan kepada masyarakat, meliputi barang (apa saja yang berbentuk fisik seperti makanan, pakaian, dan lain sebagainya), jasa (seperti perbankan, jasa pengiriman barang, lembaga zakat, dan lain sebagainya), acara (seperti yang dilakukan oleh Event Organizer), pengalaman (seperti yang dilakukan oleh Walt Disney World's Magic Kingdom, atau dilakukan oleh museum-museum), orang (seperti pemasaran selebriti), tempat (seperti tempat-tempat rekreasi), properti (real estate, saham, obligasi, dan semacamnya), organisasi (seperti yang dilakukan oleh organisasi dan atau prusahaan demi meningkatkan pamor mereka), informasi (seperti buku, produk-produk universitas, sekolah, dan sebagainya), dan terakhir adalah ide (Kotler dan Keller, 2008: 6-9).

Pada dasarnya, komunikasi merupakan kegiatan pertukaran pesan dari komuikator kepada komuikan dengan menggunakan tanda-tanda. Tanda-tanda tersebut dalam komunikasi terbagi menjadi dua bagian, yakni tanda verbal dan non-verbal. Kedua tanda ini dapat digunakan tergantung situasi dan kondisi yang mendukung kegiatan komunikasi tersebut, atau bahkan kedua tanda itu bisa digunakan secara bersamaan.

Sebagai contoh, seorang ayah misalnya, meminta bantuan kepada anaknya untuk mengambilkan sebuah buku di atas meja. Sang ayah hanya berkata "tolong ambilkan itu" sembari menunjuk pada buku yang dituju 
olehnya. Tanpa mesti mendapatkan penjelasan bahwa yang diinginkan oleh si Ayah adalah buku, sang anak pun akan dengan mudah mengerti isi pesan komunikasi yang dimaksud oleh ayahnya, untuk mengambil sebuah buku.

Dalam proses komunikasi, kerapkali melibatkan 4 faktor yang sangat dominan, yakni faktor sosial budaya, faktor hubungan sosial, faktor lingkungan fisik, dan faktor pengalaman komunikasi sebelumnya (Muhtadi, 2012: 16-17). Pertama, latar belakang sosial budaya. Semua orang pasti sedikit banyak terpengaruhi oleh sosial budaya yang melingkupi mereka. Pengaruh sosial budaya ini sejatinya mempengaruhi aspek komunikasi dalam diri seseorang. Seorang suku Sunda akan lebih nyaman berkomunikasi dengan orang yang satu suku dengannya, ketimbang dengan orang yang berbeda suku, entah itu Jawa, Batak, dan lain sebagainya.

Kedua, hubungan sosial. Setiap orang pasti memiliki hubungan sosial yang berbeda-beda dengan orang yang berbeda-beda pula. Seorang sahabat dari sejak kecil, sejatinya memiliki hubungan yang sangat intim. Mereka bisa saling membantu, saling mencurahkan isi hati, saling menasehati, bahkan saling empati. Dalam kegiatan komunikasi pun, seseorang yang sudah bersahabat sejak kecil, akan lebih egaliter dan bebas, tidak merasa terbebani dengan etika sosial apa pun. Namun, ketika tiba-tiba hubungan sosial tersebut berubah, yang satu ternyata menjadi seorang Kiyai, seorang tokoh masyarakat yang disegani, dikagumi, dan dihormati banyak orang, sedang yang satu lagi hanya menjadi orang biasa, masyarakat biasa yang status sosialnya rendah, maka kegiatan komunikasinya pun akan ikut berubah.

Ketiga, lingkungan fisik. Sejatinya lingkungan fisik juga memberikan pengaruh pada komunikasi seseorang. Dalam sebuah riungan atau acara resmi yang dihadiri banyak orang, misalkan, seseorang yang awalnya banyak bicara, kerap kali bersenda gurau dengan orang-orang di sekitarnya, tiba-tiba menjadi pendiam, berubah 180 derajat, ketika masuk kedalam ruangan tersebut. Hal ini bukan sesuatu yang aneh, melainkan sesuatu yang wajar. Seseorang biasa saja menjadi pasif dalm berkomuniksasi di ruang-ruang tertentu, namun juga bisa menjadi sangat aktiv berkomunikasi di ruang-ruang yang lain. Keempat, pengalaman komunikasi sebelumnya. Seseorang akan merasa lebih nyaman berkomunikasi dengan orang yang pernah melakukan kegiatan komunikasi dengannya sebelumnya.

Dalam kegiatan pemasaran, sejatinya komunikasi yang dilakukan tiada lain adalah untuk menarik minat atau kepercayaan masyarakat agar 
mau membeli barang atau menggunakan jasa uyang kita tawarkan. Komunikasi yang digunakan dalam kegiatan pemasaran atau marketing, adalah model komunikasi pemasaran.

Pada hakikatnya komunikasi pemasaran terbagi kedalam dua jenis komunikasi, yakni above the line dan below the line. Model komunikasi pemasaran jenis above the line, merupakan strategi komunikasi pemasaran yang memanfaatkan iklan (Rianto al-Arif, 2012: 10), baik media cetak, media massa, media elektronik, dan media-media yang lainnya seperti spanduk, bailgo, banner, pamplet dan sebagainya. Sedangkan model komunikasi pemasaran dengan jenis below the line, merupakan strategi komunikasi pemasaran yang memanfaatkan event-event tertentu, seperti kegiatan kemasyarakatan, kegiatan sosial, dan event-event lain, agar lebih menyentuh kepada masyarakatnya (al-Arif, 2012: 10).

\section{Manajemen Lazisnu Kota Bandung}

Dalam sebuah organisasi, kegiatan manajemen memang merupakan suatu hal yang paling penting. Jika sebuah organisasi gagal melakukan kegiatan manajemen, maka dapat dipastikan bahwa semua tujuan dan sasaran organisasi tersebut akan gagal dicapai. Dengan kata lain, organisasi tersebut tidak akan berjalan sesuai dengan apa yang diharapkan, atau bahkan organisasi tersebut akan mengalami "kematian" secara total. Sebagai suatu organisasi resmi, tentunya Lazisnu Kota Bandung juga melakukana kegiatan manajemen, agar dapat mewujudkan visi-misi yang telah ditentukan oleh Lazisnu.

Dari keempat fungsi manajemen yang dikemukakan Terry, yang telah dipaparkan pada bab sebelumnya, nampaknya Lazisnu sudah melakukan hal-hal tersebut. Dalam perencanaan, Lazisnu melakukannya pada rapat besar yang biasanya dilakukan diawal kepengurusan, untuk menentukan apa saja program yang akan dikerjakan oleh Lazisnu, selama masa kepengurusannya, serta menentukan berapa besaran zakat yang mesti dipungut kepada para muqakki.

Hingga saat ini, Lazisnu Kota Bandung masih memungut zakat dari para muzakki-nya sebesar 2,5\% saja, sesuai dengan yang dilakukan oleh BAZNAS. Hal ini memang sejalan dengan teori yang dikemukakan oleh hampir semua ulama klasik, bahwa standar minimum -tidak termasuk zakat pertanian- untuk zakat adalah 2,5\%. Keputusan ini bertahan hingga sekarang, dan digunakan pula oleh lembaga-lembaga amil zakat, seperti Lazisnu Kota Bandung. 
Pendapat berbeda dikemukakan oleh Fauz Noor, menurut beliau zakat dengan 2,5\% kini sudah tidak relefan lagi. Jika dari dulu hingga sekarang pemungutan zakat hanya 2,5\%, maka zakat bukan merupakan solusi kemiskinan masa kini. Menurutnya, pada zaman Isa a.s. zakat dikeluarkan sebesar 1\%, karena urusan kemiskinan pada saat itu bisa selesai dengan hanya mengeluarkan zakat 1\%. Lalu pada masa kristen sebelum Paus Paulus, zakat kristen meningkat jadi 1,5\%, karena urusan kemiskinan kembali meningkat. Baru pada saat kristen hidup di zaman Rasulullah Saw. zakat Kristen meningkat menjadi 2,5\%, karena kemiskinan pada masa itu baru terselesaikan dengan zakat 2,5\%. Menurut Noor, hal inilah yang mendasari Rasul Saw. mengeluarkan hadits bahwa zakat itu adalah 2,5\%. Noor mengungkapkan, bahwa Rasul mengadopsi konsep zakat Kristen pada masa itu, dengan menerapkan $2,5 \%$ zakat muslim. Oleh karena pertimbangan yang digunakan pada saat itu adalah kemiskinan selesai dengan hanya zakat 2,5\%, maka timbul pertanyaan, apakah di masa kini kemiskinan bisa selesai dengan hanya mengeluarkan zakat 2,5\%? Kaum Kristiani di masa kini sudah menetapkan standar minimum pembayaran zakat adalah 15\%, menurut Noor, jika kita ingin mengikuti pola pikir Rasul maka seharusnya zakat muslim pun naik jadi 15\%, atau minimal menjadi 10\% saja (Noor, 2009: 181-193).

Selain standar minimum pengeluaran zakat, dipandang penting pula adanya standar amil zakat (para pengelola zakat). Posisi amil zakat memang menjadi posisi yang paling berat dalam konsep zakat. Selain karena posisi ini mengemban amanah dari para muzakki, posisi ini pula yang menentukan akan disalurkan kemana dan untuk apa uang zakat dari para muzakk $i$ ini. Oleh karena itu, perlu ada standar yang mengatur siapa saja orang yang berhak menjadi amil zakat, ditinjau dari kredibilitasnya.

Menurut Muhammad Rasyid Ridha, seorang amil haruslah orang yang kredibel dan ditunjuk langsung oleh imam atau pemerintah (dalam hal ini Mentri Agama) untuk mengelola zakat (Ridha, 1368 H: 513, Vol: 10). Sedangkan menurut Fakhruddin al-Razi, yang mestinya menjadi amilin adalah pemerintah atau imam itu sendiri (al-Razi, 1938 H: 367, Vol: 11). Lain halnya dengan Ridha dan al-Razi, menurut Zamakhsyari siapa pun bisa menjadi amil asalkan dia di memahami tentang hukumhukum zakat, dan dipercaya oleh masyarakat (Zamakhsyari alKhawarizmi, 1433 H/ 2012 M: 262. Vol: 2). Sejalan dengan pendapat Zamakhsyari, menurut Quraish Shihab, di Indonesia pemerintah tidak ikut campur dengan masalah zakat, oleh karena itu, tidak perlu adanya syarat ditunjuk oleh pemerintah, bagi amil yang mengelola zakat, karena 
pendapat ini pun ber-ikhtilaf dikalangan para ulama sendiri (Shihab, 2004: 328).

Sedangkan pemilihan amil zakat yang dilakukan oleh Lazisnu, sebenarnya secara tidak langsung merupakan pilihan Pemerintaha (dalam hal ini Kementrian Agama), karena Lazisnu sendiri merupakan lembaga Amil Zakat yang telah diresmikan oleh negara, serta diberi wewenang untuk melakukan kegiatan pengelolaan zakat, infaq, dan shadaqah.

Selain melakukan penunjukan amil zakat, serta penentuan standar besaran zakat yang harus dipungut. Dalam proses perencanaan ini, Lazisnu Kota Bandung juga melakukan perencanaan terhadap programprogram apa saja yang akan dilakukan guna mengelola dan menyampaikan dana zakat, infaq, dan shadaqah kepada para mustabiqnya.

Adapun program-program pengelolaan dan penyampaian dana zakat, infaq, dan shadaqah Lazisnu yang saat ini telah dan sedang berjalan, ada empat program, yakni NU Care, NU Preneur, NU Smart, dan NU skill. NU Care adalah program Lazisnu Kota Bandung untuk membantu para korban-korban bencana alam. Misalkan pada saat terjadinya bencana banjir bandang di Kota Garut dan bencana longsor di Sumedang, Lazisnu Kota Bandung juga melakukan bantuan baik berupa uang, pakaian, makanan, atau pun tenaga relawan yang ikut membantu tim SAR mencari para korban. Semua bentuk bantuan tersebut (kecuali tenaga relawan) merupakan hasil pengolahan dana zakat, infaq dan shadaqah yang terkumpul dari para muzakki. Akan tetapi, karena bencana tersebut terjadi diluar kota Bandung, maka Lazisnu Kota Bandung menyalurkan bantuan mereka melalui Lazisnu yang berada diatas mereka, yakni PW Lazisnu Jawa Barat (Wawancara dengan Syahroni, direktur dari Lazisnu Kota Bandung: 19 Oktober 2016).

Berikutnya program NU Preneur. Program ini ditujukan untuk memberikan modal kepada para pemilik usaha mikro, untuk mengembangkan usahanya menjadi lebih baik. Tak hanya untuk orang yang memang sudah memiliki usaha mikro, namun program ini juga diperuntukkan bagi siapa saja warga kota Bandung yang memiliki keinginan untuk membuka usaha, maka akan diberikan uang modal. Melalui program ini, Lazisnu ingin merubah mustahiq menjadi seorang muzakki. Hal ini sejalan dengan teori yang diungkapkan oleh Jalaluddin Rakhmat, bahwa Zakat bukan hanya kegiatan memberi kepada mustabiq, namun juga berusaha untuk menjadikan mustabiq sebagai muzakki (Rakhmat, 1998: 242). 
Program NU Preneur ini tentunya bukan hanya memberikan modal kepada pemilik usaha mikro atau kepada orang yang ingin membuka usaha, namun jelas dibarengi dengan adanya kegiatan pengawasan yang dilakukan oleh pihak Lazisnu Kota Bandung sendiri. Pengawasan ini juga tentunya bertujuan untuk menghindari adanya penyalahgunaan dana zakat, infaq dan shadaqah yang dilakukan oleh para penerima dana tersebut dalam program NU Preneur. Jika ternyata usaha yang dilakukan oleh penerima dana tersebut maju, maka sang penerima dana dituntut untuk mengeluarkan zakatnya kepada Lazisnu Kota Bandung, guna terjadinya keberlanjutan hubungan antara Lazisnu dan penerima dana. Namun apabila usaha orang tersebut tidak berjalan baik, atau bahkan dana yang diberikan diselewengkan, maka hal ini akan dikaji lebih lanjut oleh pihak Lazisnu, apakah dana tersebut akan dihentikan, atau mungkin akan dilanjutkan, melihat potensi yang ada.

Khusus untuk orang-orang yang baru mau memulai usaha mikronya, Lazisnu tidak akan langsung memberikan dana sebagaimana orang yang sudah memiliki usaha mikro. Namun orang tersebut akan terlebih dahulu mengikuti program NU Skill, dimana orang itu akan dilatih sedemikian rupa untuk mengembangkan minat dan bakatnya di dunia usaha, guna memberikan keterampilan dan wawasan terkait usaha yang akan ia jalani. Setelah orang tersebut mengikuti program NU Skill dengan baik, maka jika pihak Lazisnu Kota Bandung memandang bahwa orang tersebut memiliki potensi untuk membuka usaha mikro, maka barulah Lazisnu Kota Bandung memberikan bantuan modal sesuai dengan ketentuan yang berlaku pada program NU Preneur.

Namun, program NU Skill tidak hanya melakukan pelatihan kepada calon penerima dana NU Preneur, melainkan juga melakukan kegiatan pelatihan terhadap para relawan-relawan, untuk selanjutnya disiapkan menjadi tenaga marketing. Contoh kasusu, pada bulan agustus kemarin, program NU Skill ini telah memberikan pelatihan dan pembekalan terhadap 27 relawan-relawan yang berasal dari beragam latar belakang(ada yang berstatus sebagai mahasiswa, guru sekolah, penyuluh agama dan lain sebagainya). Mereka diberikan pengarahan, pelatihan, dan pembekalan, khususnya dibidang public speaking dan public relation, untuk kemudian menjadi tenaga marketing, menarik minat dan kepercayaan dari masyarakat.

Program keempat dari Lazisnu, yakni NU Smart. Program ini bertujuan untuk memberikan bantuan dana pendidikan kepada pelajar Kota Bandung yang kurang mampu secara financial. Memang program ini tidak memberikan bantuan secara penuh kepada pelajar-pelajar yang 
kurang mampu -tidak seperti program Bidik Misi yang menjamin secara penuh para pelajar yang kurang mampu, dari mulai biaya administratif, hingga biaya hidup sehari-hari - namun demikian, melalui program ini, Lazisnu Kota Bandung dapat sedikit membantu pelajar-pelajar Kota Bandung yang berprestasi, namun kurang mampu dalam segi ekonomi. Program ini masih terbatas hingga pendidikan jenjang S1, belum sampai ke jenjang pendidikan S2 atau S3. Program ini sebenarnya ikut serta membantu program pemerintah Kota Bandung yang mencanangkan program "1 rumah, 1 Sarjana", jadi dana yang digunakan untuk menjalankan program ini pun bukan hanya merupakan hasil pengumpulan infaq, zakat, dan shadaqah dari para murakki saja, melainkan juga ada sedikit bantuan dari pemerintah Kota Bandung, demi kelancaran program mereka (Wawancara dengan KH. Umar Mahsur, Ketua Umum PC Lazisnu Kota Bandung: 20 Oktober 2016).

Untuk mengikuti program ini pun terbilang cukup mudah, hanya menyerahkan beberapa syarat administratif, kemudian pihak Lazisnu Kota Bandung akan melakukan pengamatan dan survei ke rumah calon penerima dana, memastikan bahwa calon penerima dana memang benarbenar berasal dari keluarga tidak mampu, sebelum akhirnya diberikan dana pendidikan. Tak hanya sampai di situ, pihak Lazisnu Kota Bandung juga akan terus memantau kegiatan belajar siswa tersebut, dan menentukan apakah program NU Smart ini akan dilanjutkan pada anak tersebut, atau dihentikan.

Dari keempat program besar Lazisnu Kota Bandung ini, maka dapat dipastikan bahwa memang pengelolaan zakat, infaq dan shadaqah yang dilakukan oleh Lazisnu Kota Bandung memang merupakan suatu upaya untuk mengatasi kemiskinan. Disamping itu, melalui programprogram tersebut, sejatinya Lazisnu Kota Bandung tengah melakukan kegiatan dakwah berupa tathwir, dimana mereka mengubah nilai-nilai ajaran Islam kedalam pengamalan melalui pemberdayaan sumber daya manusia, lingkungan serta ekonomi (Enjang, 2011: 471-471. Vol: 5. No. 2). Hal ini sejalan dengan tujuan utama dari adanya tuntutan zakat, yakni mengatasi kemiskinan di muka bumi ini. Sebagaimana diterangkan dalam QS. At-Taubah ayat 60:

"Sesungguhnya sedekah (zakat) itu, diperuntukkan bagi orangorang faqir, orang-orang miskin, para 'amilin (pengurus zakat), para mualaf yang dibujuk hatinya, orang-orang (yang memerdekakan) budak, orang-orang yang berhutang, sabilillah (orang-orang yang berperang di jalan Allah), dan ibnu sabil (musafir yang kehabisan ongkos). Sebagai suatu ketetapan dari Allah. Dan Allah Maha 
Mengetahui lagi Maha Bijaksana" (Al-Qur'an al-Karim, 1418 H: 288).

Menurut Zamakhsyari, kalimat "Sesungguhnya sedekah (zakat) itu, diperuntukkan bagi orang-orang faqir, orang-orang miskin......" sudah menunjukkan bahwa zakat yang diperintahkan oleh Tuhan merupakan solusi mengatasi kemiskinan yang disodorkan oleh al-Qur'an (Zamakhsyari al-Khawarizmi, 1433 H/ 2012 M: 263. Vol: 2).

Bahkan menurut Fauz Noor, urusan ketauhidan yang paling mendasar bukanlah meng-Esa-kan Tuhan (karena Tuhan sudah Esa tanpa di-Esakan oleh manusia) atau pun wabdaniyah, melainkan menyelesaikan kemiskinan dan ketimpangan sosial. Hal ini dapat dibuktikan dengan kronologis turunnya al-Qur'an dari surat yang pertama turun (surat al-A'laq) hingga surat yang turun pada urutan ke 19 (surat al-Ikhlas) (Noor,2009: 172-174). Dalam ayat-ayat yang turun di awal kerasulan itu, terdapat begitu banyak masalah keserakahan, kekayaan, dan ketidakpedulian sosial. Hal ini menunjukkan bahwa Tuhan memberikan perhatian khusus terhadap hala-hal tersebut (Noor,2009: 175). Setelah 18 surat yang turun menyoroti masalah-masalah diatas, barulah pada surat ke 19 (surat al-Ikhlas) Tuhan bicara tentang wabdaniyah. Artinya, seharusnya manusia baru mengurusi urusan wahdaniyah Tuhan jika masalah keserakahan, kekayaan, ketidakpedulian sosial, kemiskinan, serta ketimpangan sosial-ekonomi sudah diselesaikan.

Pandangan serupa juga dikemukakan oleh Fazlur Rahman. Menurut beliau, tujuan hakiki dari diturunkannya al-Qur'an adalah untuk menciptakan tatanan asyarakat yang etis dan egaliter, hal ini terlihat dari bagaimana al-Qur'an mencela sedemikian rupa tentang disekuilibrium ekonomi dan ketidakadilan sosial, bahkan lebih jauh al-Qur'an pun tidak setuju dengan adanya politheisme yang merupakan penyebab adanya segmentasi masyarakat, dan ketimpangan sosio-ekonomi (Rahman, 1983: $55)$.

Setidaknya ada tiga alasan mengapa zakat menjadi kewajiban dan tuntutan bagi setiap muslim. Pertama, karena perintah Tuhan dalam alQur'an. Manusia merupakan khalifah (wakil/pengganti) Allah di muka bumi, untuk mengurusi apapun yang ada di muka bumi ini, termasuk didalamnya urusan harta. Sejatinya, Tuhan memerintahkan anusia untuk menggunakan harta demi kemanfaatan bersama. Kedua, solidaritas sosial. Manusia adalah makhluk sosial. Seseorang tidak akan pernah meraih apa yang diinginkannya dengan usaha sendiri, malinkan juga mesti dibantu oleh orang lain. Seorang petani misalnya, tidak mungkin dia menuai panen yang diinginkan jika tanpa ada bantuan irigasi, stabilitas keamanan, 
pangan, pakaian, dan lain sebagainya. Untuk itulah zakat mesti dikeluarkan sebagai solidaritas sosial. Ketiga, persaudaraan. Setiap muslim adalah saudara. Dengan adanya kesadaran persaudaraan inilah, tumbuh nurani untuk menyisihkan sebagian harta untuk orang yang membutuhkan, baik berupa tuntutan zakat, maupun anjuran shadaqah, dan sebagainya (Shihab, 2004: 323-325).

Kemiskinan dimuka bumi ini tidak dapat diselesaikan oleh hanya sekedar mengandalkan keinsafan individual masyarakat. Karena toh hanya sedikit masyarakat yang memiliki kepedulian sosial dengan memberikan sebagian hartanya secara suka rela kepada saudaranya yang membutuhkan. Oleh karena itu, hadirnya zakat menjadi solusi untuk menyelesaikan kemiskinan tersebut. Zakat bukan merupakan pungutan secara suka rela, melainkan juga merupakan sebuah tuntutan yang mesti dipenuhi (Shihab, 2004: 455). Bahkan pada zaman Abu Bakr as-Shiddiq, hukuman mati diberikan kepada mereka para pembangkang yang tak ingin membayar zakat (Haekal, 2014: 87-97). Banyak terjadi polemik diantara para ulama tentang apa yang menjadi alasan Abu Bakr memberantas para pembangkang zakat. Ada yang mengatakan bahwa ini memang merupakan perintah yang dinisbahkan dari Rasul, meski Rasul tidak memerintahkan langsung melalui haditsnya, ada pula yang berpendapat bahwa tindakan pemberantasan yang dilakukan oleh Abu Bakr terhadap para pembangkang zakat adalah murni pertimbangan politik, karena memang tidak ada baik ayat al-Qur'an maupun Hadits Rasul yang memerintahkan untuk membunuh orang-orang yang tidak membayar zakat (Hitti, 2013: 217-220) (Husain, 2000: 53-92). Terlepas dari polemik ini, hukum membayar zakat tetaplah merupakan kewajiban dan tuntutan yang mesti dipenuhi

Selanjutnya pada tataran pengorganisasian sesuai dengan fungsi manajemen berikutnya, Lazisnu telah melakukannya sesuai dengan kebutuhan mereka. Penasehat dan Pembina dalam Struktur PC Lazisnu Kota Bandung, bertugas untuk melakukan pengawasan sekaligus sebagai konsultan bagi para pengurus lainnya. Sedangkan untuk Ketua Umum, Bendahara Umum, dan Sekretaris Umum, bertugas untuk melakukan perencanaan kegiatan-kegiatan yang akan dilakukan oleh Lazisnu, serta melakukan evaluasi-evaluasi terhadap kinerja organisasi. Selain itu, mereka juga bertugas melakukan pengawasan dan pengarahan kepada jajaran yang berada dibawahnya. Adapun kehadiran Direktur beserta stafnya (Staf Keuangan dan Staf Administrasi), bertugas sebagai pengorganisir dan pelaksana dari semua kegiatan-kegiatan yang telah direncanakan, serta melakukan koordinasi dengan para relawan yang 
tersebar. Selain itu, Direktur beserta stafnya juga bertugas melaporkan apa pun yang terjadi dilapangan, entah itu baik atau pun buruk, kepada Ketua Umum Lazisnu Kota Bandung.

Sebenarnya, pada tataran pengorganisasian ini masih banyak yang mesti diperbaiki oleh PC Lazisnu Kota Bandung. Masalah utama yang sebenarnya dihadapi oleh Lazisnu Kota Bandung ini adalah ketidakfokusan para pelaku organisasi tersebut. Disadari atau tidak, semua orang yang terlibat dalam organisasi Lazisnu Kota Bandung melakukan kegiatan organisasi dengan tenaga sisa kegiatan rutin mereka. Tidak ada yang fokus bekerja di organisasi tersebut, kecuali Direkturnya. Kendala ini juga sebenarnya disadari oleh semua orang yang terlibat, namun mereka juga tidak bisa berbuat banyak. Penyebab ketidak fokusan ini terjadi, tiada lain dikarenakan tidak adanya upah yang layak bagi para pelaku organisasi ini. Kalaupun upah itu ada, mungkin hanya alakadarnya, tidak dapat menutupi kebutuhan hidup mereka masingmasing.

Karena faktor itulah, para penggerak Lazisnu Kota Bandung tidak terlalu fokus terhadap Lazisnu sendiri. Mungkin hal ini juga dapat dimaklumi, mengingat status mereka yang sudah berkeluarga, dan memiliki beban kebutuhan masing-masing. Jadi sebenarnya Lazisnu Kota Bandung ini dijalankan oleh orang-orang yang memang benar-benar ikhlas melakukannya, didasari atas kecintaan mereka terhadap Nahdlatul Ulama.

Selanjutnya fungsi ketiga dari manajemen yang juga telah dilakukan oleh Lazisnu Kota Bandung, yakni pengawasan. Setiap program yang dilaksanakan oleh Lazisnu Kota Bandung memang sealu diawasi, baik itu kinerjanya, hingga pencapaian yang didapatnya. Jika dipaparkan, kegiatan pengawasan yang dilakukan oleh Lazisnu Kota Bandung merupakan pengawasan bertingkat, dari mulai pengawasan yang dilakukan oleh pejabat organisasi paling tinggi (Penasehat dan Pembina), hingga pengawasan yang dilakukan oleh pejabat organisasi paling rendah (Direktur beserta stafnya). Penasehat dan Pembina mengawasi kinerja dari Ketua Umum dan jajarannya. Mereka lebih menekankan pada pengawasan program-program kerja yang di launcing-kan oleh Ketua Umum dan jajarannya. Jika ternyata program tersebut tidak relevan dengan visi-misi Lazisnu, maka Ketua Umum dan jajarannya akan mendapatkan teguran. Yang paling aktiv melakukan pengawasan terhadap kinerja Lazisnu, adalah Dr. Nur Hidayat. Beliau menjabat sebagai pengawas kinerja PC Lazisnu Kota Bandung, sekaligus sebagai penasehat organisasinya. Selain itu, beliau juga merupakan konsutan 
keuangan dan konsultan pajak. Profesinya ini juga membuat beliau sangat kredibel dengan Lazisnu, khususnya dibidang keuangan.

Ketua Umum beserta jajarannya pula melakukan pengawasan serupa, kepada Direktur dan stafnya. Pengawasan ini bertujuan untuk mengaping kinerja yang dilakukan oleh Direktur dan stafnya, dalam pelaksanaan program yang sudah direncanakan. Sedangkan Direktur beserta Stafnya melakukan pengawasan kepada seluruh kinerja relawan yang bekerja dilapangan, dan juga melakukan pengawasan pada setiap program kerja yang dilakukan, seperti NU Preneur, NU Skill, NU Care, dan NU Smart, yang mana keempat program ini memang membutuhkan pengawasan ekstra, guna menghindari terjadinya kecurangan dilapangan.

Setelah proses pengawasan ini dilakukan, maka terakhir, evaluasi pun digelar. Biasanya evaluasi paling rutin dilakukan sebulan sekali pada saat rapat bulanan. Kegiatan rapat evaluasi di Lazisnu Kota Bandung ini biasanya dilakukan oleh Ketua Umum hingga pada tingkat relawan. Rapat evaluasi ini dilakukan guna membenahi kinarja Lazisnu yang dianggap masih belum maksimal, menemukan kendala apa yang menghambat kinerja, hingga mencari solusi untuk memperbaiki kinerja tersebut. Tak hanya pada rapat bulanan, rapat tahunan pun juga tidak luput dari kegiatan evaluasi, namun bedanya, pada rapat tahunan ini biasanya juga dihadiri oleh jajaran Penasehat dan Pembina.

\section{Komunikasi Marketing PC Lazisnu Kota Bandung}

Program-program yang telah dicanangkan oleh Lazisnu Kota Bandung diatas, akan menjadi sangat sia-sia jika tidak ditunjang oleh para muzakki. Oleh karena itu, sudah barang tentu menjadi tugas pokok dari Lazisnu untuk menarik minat dan kepercayaan masyarakat, dalam menitipkan zakat, infaq, dan shadaqahnya kepada Lazisnu Kota Bandung.

Untuk menarik minat masyarakat tersebut, Lazisnu jelas menggunakan metode marketing yang cukup terorganisir. Kegiatan marketing yang dilakukan oleh Lazisnu bertujuan untuk saling menguntungkan antara Lazisnu (karena dapat menjalankan programprogramnya), juga menguntungkan bagi para muqakki (karena merasa zakat, infaq, dan shadaqahnya sudah dikeluarkan tepat sasaran).

Kegiatan marketing yang saling menguntungkan ini, sesuai dngan teori marketing yang dikemukakan oleh beberapa ahli dan asosiasi marketing. Seperti yang dikemukakan oleh American Marketing Association (AMA) bahwa marketing atau pemasaran merupakan sebuah 
fungsi dari organisasi serta serangkaian proses untuk menghasilkan, mengkomunikasikan, serta memberikan nilai kepada para konsumen dan produsen hubungan pelanggan dengan cara yang saling menguntungkan satu sama lain (Rianto al-Arif, 2012: 6).

Sebagaimana yang telah dikemukakan oleh Kotler dan Keller pada bab sebelumnya, bahwa entitas yang dipasarkan terdiri dari sepuluh entitas (Kotler dan Keller, 2008: 6-9). Entitas yang dipasarkan oleh Lazinu Kota Bandung adalah berupa jasa dan organisasi. Lazisnu Kota Bandung menawarkan jasa pengelolaan zakat, infaq, dan shadaqah, serta jasa penyaluran dana tersebut kepada orang-orang yang memang membutuhkan melalui program-program mereka, juga menawarkan jasa pemerataan pembagian dana tersebut kepada para mustahiq yang tersebar di kota Bandung. Selain itu, dalam tataran praktisnya, Lazisnu juga memasarkan organisasinya guna mendapatkan pamor yang baik, untuk kemudian meraih kepercayaan dari masyarakat.

Kegiatan komunikasi marketing yang dilakukan oleh Lazisnu, sejatinya tidak terlepas dari 4 faktor yang mempengaruhi komunikasi, yakni faktor sosial budaya, faktor hubungan sosial, faktor lingkungan fisik, dan faktor pengalaman komunikasi sebelumnya (Muhtadi, 2012: 1617). Pada faktor pertama, sebenarnya bukan hanya sosial budaya yang diciptakan oleh latar belakang kesukuan yang mempengaruhi komunikasi Lazisnu, sosial budaya yang diciptakan oleh latar belakang organisasi dan lingkungan hidup pun berpengaruh terhadap komunikasi Lazisnu. Misalnya, seorang warga Nahdliyin akan lebih canggung jika mesti berkomunikasi dengan orang Persis atau Muhammadiyah, begitu pun sebaliknya. Maka dari itu, Lazisnu Kota Bandung memanfaatkan hal faktor ini untuk menarik kepercayaan masyarakat Nahdliyin. Masyarakat Nahdliyin jelas akan lebih memilih membayar zakat, infaq, dan shadaqah kepada Lazisnu, daripada membayar kepada lembaga lain, yang masyarakatnya sendiri tidak tahu latar belakang lembaga tersebut seperti apa.

Faktor hubungan sosial juga sangat diperhatikan oleh Lazisnu Kota Bandung. Sebelum mereka mendatangi seseorang, terlebih dahulu mereka akan melihat status sosial mereka, khususnya status orang-orang tersebut dalam kepengurusan Nahdlatul Ulama. Jika ternyata orang tersebut memiliki jabatan yang tinggi di kepengurusan Nahdlatul Ulama, maka bukan orang-orang sekelas relawan yang akan menghadapi, tapi oleh para petinggi Lazisnu Kota Bandung sendiri.

Dalam faktor lingkungan fisik, Lazisnu kota Bandung lebih cenderung melakukan komunikasi antarpribadi, yang mana para 
komunikator aktiv mendatangi rumah-rumah (dor to dor) para calon muzakki. Suasana dirumah tersebut, diyakini menjadi faktor pendukung untuk terjadinya komunikasi marketing yang efektif.

Terakhir faktor pengalaman komunikasi sebelumnya. Pihak Lazisnu Kota Bandung akan merasa lebih nyaman berkomunikasi dengan muzakki yang pernah berkomunikasi sebelumnya. Terlebih jika pada pertemuan pertama, kesan yang diberikan adalah kesan yang positif. Lain halnya jika pada pertemuan sebelumnya kesan yang muncul adalah kesan yang negatif, maka mungkin komunikasi akan berjalan tidak lancar di pertemuan-pertemuan berikutnya.

Disamping 4 faktor tadi, dalam menawarkan jasa dan organisasinya kepada masyarakat, Lazisnu Kota Bandung menggunakan metode komunikasi yang bisa dibilang cukup efektif guna meraih simpatik masyarakat. Kegiatan komunikasi dapat berhasil jika menggunakan strategi yang baik. Pada hakikatnya, strategi merupakan kegiatan perencanaan serta manajemen guna mencapai hasil yang telah ditentukan. Akan tetapi, untuk sampai pada hasil yang telah ditentukan tersebut, strategi bukan sekedar menjadi penunjuk arah belaka, namun juga mesti menuntun kepada sebuah taktik operasionalnya (Mukarom, 2011: 617. Vol-5. No. 2). Guna meraih simpatik masyarakat dan menambah jumlah muzakkinya, strategi komunikasi yang digunakan Lazisnu Kota Bandung yakni memakai model komunikasi pemasaran above the line dan below the line.

Model komunikasi pemasaran jenis above the line, yang merupakan strategi komunikasi pemasaran yang memanfaatkan iklan (Rianto al-Arif, 2012: 10), sebagaimana dikemukakan pada bab sebelumnya, baik media cetak, media massa, media elektronik, dan media-media yang lainnya. Lazisnu Kota Bandung melakukan promosi dengan cara membuat brosur yang dibagikan oleh relawan secara dor to dor. Membuat banner, spanduk, dan neon box di kantor resmi PC Lazisnu Kota Bandung, di Jl. Sancang, Kota Bandung.

Sedangkan model komunikasi pemasaran dengan jenis below the line, yang merupakan strategi komunikasi pemasaran dengan memanfaatkan event-event tertentu, seperti kegiatan kemasyarakatan, kegiatan sosial, serta event-event lain, guna menyentuh masyarakatnya (Rianto al-Arif, 2012: 10). Model komunikasi marketing ini juga digunakan oleh Lazisnu pada event-event tertentu, seperti pada saat Peringatan Hari Besar Islam (PHBI) yang diselenggarakan oleh PCNU Kota Bandung, kegiatankegiatan sosial yang diselenggarakan oleh Pemkot Bandung, serta kegiatan-kegiatan lainnya. Contoh kasus, ketika kemarin tanggal 22 
oktober, PCNU menggelar konvoi santri dalam rangka memeriahkan Hari Santri, Lazisnu dengan sigap membagikan brosur-brosur dan pamplet.

Selain itu, jenis komunikasi below the line ini juga dimanfaatkan oleh Lazisu untuk meraih simpatik dari para Kiyai yang menjadi amil zakat personal, agar mau bekerja sama dengan Lazisnu dalam pengolahan dan pembagian dana zakat, infaq, dan shadaqah. Komunikasi ini dilakukan pada event-event pertemuan yang diselenggarakan oleh PCNU Kota Bandung, dengan para Kiyai-Kiyai NU se-Kota Bandung. Lazisnu Kota Bandung menggunakan kedua model komunikasi marketing ini tiada lain untuk memperluas jangkauan mereka (pasar), serta menarik muzakkimuzakki yang baru. Sebagaimana dikemukakan oleh Andrzej Kobylanski dan Radoslaw Szulc dalam jurnalnya, bahwa strategi menemukan konsumen baru merupakan aspek yang sangat penting untuk sebuah organisasi perusahaan (Kobylanski dan Szulc, 2011: 54. Vol: 4. No. 1).

Bagi para murakki dan mushaddiq (orang yang mengeluarkan shadaqah) yang sudah berkenan untuk menyalurkan zakatnya kepada Lazisnu, mereka diberikan keleluasaan untuk membayarkan zakat, infaq, dan shadaqahnya melalui cara apapun yang diinginkan. Jika mereka menghendaki untuk membayarkannya via transfer, maka Lazisnu memfasilitasinya dengan membuat beberapa rekening Bank, guna menerima dana zakat, infaq, dan shadaqahnya dari para muzakki dan mushaddiq-nya. Sampai saat ini, Lazisnu baru memiliki dua rekening Bank di dua Bank berbeda. Rencananya, Lazisnu Kota Bandung ingin membuka rekeneing disemua Bank, guna mempermudah muzakki dan mushadiq yang ingin menyalurkan danannya.

Namun, jika muzakki atau mushaddiq menghendaki dana zakat, infaq, dan shadaqahnya dijemput ke rumah mereka, maka para relawan Lazisnu Kota Bandung pun dengan sigap menjemput ke rumah para murakeki dan mushaddiq-nya.

\section{Penutup}

Komunikasi marketing yang digunakan oleh Lazisnu Kota Bandung, menggunakan dua model komunikasi marketing, yakni above the line dan below the line. Dalam model yang pertama, Lazisnu melakukannya dengan cara dor-to-dor ke rumah-tumah calon muzakki. Disana para relawan menawarkan program-program dan kinerja yang dilakukan oleh Lazisnu dalam mengelola dan menyalurkan dana zakat, infaq, dan shadaqah dengan tepat sasaran. Selain itu, para relawan juga memeberikan brosur 
dan pamplet kepada para calon muzakki, untuk dipelajari lebih lanjut mengenai program-program dari Lazisnu Kota Bandung.

Untuk model below the line, Lazisnu Kota Bandung memanfaatkan acara-acara PHBI yang diselenggarakan oleh PCNU Kota Bandung, memanfaatkan acara-acara yang diselenggarakan oleh Pemkot Bandung, dan menggelar acara-acara sendiri, seperti santunan anak yatim, buka bersama, istighasah, dan lain sebagainya. Selain untuk menarik minat dan kepercayaan masyarakat, model below the line ini juga dimanfaatkan Lazisnu Kota Bandung untuk bekerja sama dengan para Kiyai yang menjadi amil zakat secara personal.

Kegiatan manajemen yang dilakukan oleh Lazisnu Kota Bandung, meliputi kegiatan perencanaan, pengorganisasian, pengawasan, serta evaluasi. Perencanaan dilakukan pada rapat besar yang dilakukan diawal kepengurusan, meliputi perencanaan program yang akan dilakukan guna mengelola dan menyalurkan dana zakat, infaq, dan shadaqah, penentuan standar minimum penariakan zakat, dan penentuan orang-orang yang akan dijadikan sebagai amil zakat.

Pengorganisasian dilakukan oleh Lazisnu sesuai dengan kebutuhan mereka, meliputi Penasehat dan Pembina yang melakukan controling dan bertindak sebagai konsultan. Ketua Umum dan jajarannya (Bendahara Umum dan Sekretaris Umum), bertindak sebagai perencana kegiatan, melakukan evaluasi kegiatan, serta melakukan pengawasan kepada jajaran dibawahnya. Direktur dan Stafnya (Keuangan dan Administrasi), bertgas sebagai pelaksana program kegiatan yang telah direncanakan, melakukan koordinasi dengan para relawan yang bertugas dilapangan, serta melaporkan hasil kerja kepada Ketua Umum.

Sementara itu, untuk kegiatan pengawasan, Lazisnu Kota Bandung melakukan pengawasan bertingkat, dimana pejabat organisasi yang lebih tinggi mengawasi kinerja pejabat lain yang lebih rendah. Pembina dan Penasehat mengawasi kinerja Ketua dan jajarannya. Ketua dan jajarannya mengawasi kinerja Direktur beserta Stafnya. Direktur dan Stafnya melakukan pengawasan pada kinerja relawan, serta melakukan pengawasan pada program-program yang dikerjakan oleh mereka.

Terakhir, Lazisnu melakukan evaluasi bulanan dan evaluasi tahunan. Kegiatan ini bertujuan untuk menemukan apa saja yang menjadi penghambat kinerja seluruh anggota Lazisnu dari mulai Ketua Umum hingga relawan, baik itu kegiatan penarikan minat masyarakat, pengolahan dana zakat, serta penyebarannya. Kegiatan ini juga bertujuan untuk mencari solusi apa yang tepat, untuk mengatasi kendala-kendala yang dihadapi. 
Lazisnu menggunakan 4 program untuk menyebarkan dana zakat, infaq, dan shadaqah, dari para muzakki dan mushaddiq-nya. Programprogram tersebut meliputi NU Care, NU Preneur, NU Skill, dan NU Smart. NU Care bertujuan untuk menyebarkan dana zakat, infaq, dan shadaqah kepada para korban bencana alam. Sedangkan NU Skill mencoba untuk memberikan keterampilan dan pengarahan kepada masyarakat yang ingin membuka usaha mikro. Program NU Preneur bertujuan untuk membagikan dana zakat, infaq, dan shadaqah untuk kemudian dijadikan modal bagi orang yang memiliki usaha mikro, atau pun orang yang baru berniat membuka usaha mikro (yang sebelumnya sudah mengikuti program NU Skill). Program ini juga bertujuan untuk merubah seorang mustahiq menjadi muгakki. Terakhir adalah program NU Smart. Dalam program ini dana zakat, infaq, dan shadaqah disalurkan untuk dana pendidikan anak-anak bangsa yang kurang mampu, hingga pada jenjang sarjana.

\section{Daftar Pustaka}

Abu al-Qasim Muhammad bin Umar bin Zamakhsyari al-Khawarizmi, $(1433 \mathrm{H} / 2012 \mathrm{M})$ al- Kasyaf 'an Haqaiaqi al-Tanæil wa 'Uyuni alTa'wil fi Wujubi al-Ta'wil. Darul Hadits al-Qahirah, Qahirah Libanon. Vol: 2 Al-Qur'an al-Karim

Asep Saeful Muhtadi, (2012). Komunikasi Dakwah. Simbiosa, Bandung.

Fakhruddin al-Razi, (1938 H). Tafsir Kabir: Mafatih al-Ghaib. Al-Mathba'ah al-Mishriyah, Mesir.

Fauz Noor, (2009). Berpikir Seperti Nabi: Perjalanan Menuju Kepasrahan. LKiS, Yogyakarta.

Fazlur Rahman, (1983). Tema Pokok al-Qur'an. (Trans: Anas Mahyuddin)Pustaka, Bandung.

Jalaluddin Rakhmat, (1998). Islam Aktual. Mizan Bandung.

Rosda Karya, Bandung. (2000). Metode Penelitian Komunikasi, PT. Remaja

M. Nur Rianto al-Arif, (2012). Dasar-Dasar Pemasaran Bank Syari'ah. Alfabeta, Bandung.

M. Quraish Shihab, (2004). Membumukan al-Qur'an. Mizan, Bandung. , (2004). Wawasan al-Qur'an. Mizan, Bandung.

Muhammad Firdaus, (2009). Manajemen Agribisnis. PT Bumi Aksara: Jakarta.

Muhammad Husain Haekal, (2014). Abu Baker as-Siddiq. (Trans: Ali Audah), Litera AntarNusa, Jakarta. 
Muhammad Rasyid Ridha, (1368 H). Tafsir al-Manar. Al-Manar, Mesir. Vol: 10

Philip K. Hitti, (2013). History of the Arabs. (Trans: R. Cecep Lukman Yasin \& Dedi Slamet

Riyadi). Serambi, Jakarta.

Philip Kotler dan Kevin Lane Keller, (2008). Manajemen Pemasaran. (Trans: Bob Sabran), Erlangga, Bandung.

Sugiyono, (2013). Memahami Penelitian Kualitatif, Alfabeta, Bandung.

Thaha Husain, (2000). Dua Tokoh Besar dalam Sejarah Islam: Abu Bakr dan Umar. (Trans: Ali Audah). Pustaka Jaya, Jakarta.

Andrzej Kobylanski dan Radoslaw Szulc, (2011). Development of Marketing Orientation in Small and Medium-Sized Enterprises: Evidence from Estern Europe. International Journal of Management and Marketing Research. Vol-4. No 1.

Dadan Anugerah, (2011). Marketing Politik: Urgensi dan Posisinya dalam Komunikasi Politik. Jurnal Ilmu Dakwah. Vol-5. No. 2

Enjang A.S, (2011). Pengembangan Masyarakat Islam dalam Siste Dakwah. Jurnal Ilmu Dakwah Vol. 5 No. 18

Irfan Syauqi Beik, (2009). Analisis Peran Zakat dalam Mengurangi Kemiskinan: Studi Kasus Dompet Dhuafa Republika. Jurnal Pemikiran dan Gagasan. Vel-2. No 1

Zaenal Mukarom, (2011). Strategi Komunikasi Politik Perempuan di Lembaga Legislatif. Jurnal Ilmu Dakwah. Vol-5. No. 2 
M. Abdul Ghani 